\title{
MERETAS PENDIDIKAN TERINTEGRATIF PADA MATA KULIAH PENDIDIKAN KEWARGANEGARAAN DI PERGURUAN TINGGI KEAGAMAAN ISLAM NEGERI: Transformasi Ideologi Pancasila dan Deradikalisasi
}

\author{
Arief Adi Purwoko \\ Institut Agama Islam Negeri Pontianak, Indonesia \\ ariefadipurwoko@iainptk.ac.id
}

\begin{abstract}
Ideology is an important part of human life, both as ideals and the system of thinking. Nevertheless not many realize, that ideology is a construction, either consciously or naturally formed. This article is a literature study, in an effort to uncover and illustrate contemplatively the development of education of ideology, especially by placing civic education at Perguruan Tinggi Keagamaan Islam Negeri (PTKIN) as a filter of the radicalisation. The strategy offered is the adoption of integrated curriculum to raise students' conscientization. The article discusses the transformation of Pancasila ideology through: i) urgency of civic education in PTKIN; II) The role of PTKIN to convey Pancasila as national ideology; and (iii) an integrated curriculum model in civic education as an ideological transformation effort. The discussion will begin from the role of PTKIN as a government representative in implementing education, which is to educate citizens as well as assert Pancasila as a nation's ideology. PTKIN must be able to translate the universal values of Islam and Pancasila, without any conflict. At the same time, the citizenship education in it does not have to be interpreted as a doctrinal space, but rather a dialogical space between the universal values of which - manifested in both the theory and the legal evidence in various events. It will also comparatively describe that "stick and carrot model" would rather keep away from education goals, only create fear, and not differ from the pattern of a radicalism. In conclusion, the integrated curriculum involves the creation of products from various branches of science, multidisciplinary, especially from the scientific work that has been produced by PTKIN, as well as studies adopted from Islamic Studies. By adopting the integrated curriculum, hopefully, will be formed a holistic understanding of students, so that with the conscientization, independently will be able to analyse the threat of radicalism for the existence of the Republic of Indonesia.
\end{abstract}

Keywords: Civic Education, PTKIN, Integrated Curriculum

\begin{abstract}
Abstrak: Ideologi merupakan hal penting dalam kehidupan manusia, sebagai cita-cita sekaligus sistem pemikiran yang mengendalikan perilaku di dalamnya, termasuk dalam diskursus kebangsaan dan kenegaraan. Meskipun demikian tidak banyak yang menyadari, bahwa ideologi merupakan sebuah konstruksi, baik secara sadar dibentuk atau secara alamiah terbentuk. Artikel ini merupakan studi kepustakaan, berupaya menguak secara deskriptif-kontemplatif perkembangan pendidikan ideologi terutama dengan menempatkan Pendidikan Kewarganegaraan di Perguruan Tinggi Keagamaan Negeri (PTKIN) sebagai filter dari upaya radikalisasi. Tidak dapat dipungkiri, teknologi informasi dan komunikasi ikut andil di dalamnya. Strategi yang ditawarkan meliputi adopsi terhadap pendidikan terintegratif dengan meretas kesadaran kritis pebelajar. Artikel membahas transformasi ideologi Pancasila melalui: i) urgensi
\end{abstract}


JRTIE: Journal of Research and Thought of Islamic Education

Vol. 3, No. 1, 2020

Pendidikan Kewarganegaraan di PTKIN; ii) peran PTKIN sebagai penegas ideologi Pancasila; dan (iii) model pendidikan terintegratif dalam Pendidikan Kewarganegaraan sebagai upaya transformasi ideologi. Pembahasan akan dimulai dari peran PTKIN sebagai kepanjangan tangan pemerintah di bidang pendidikan, yakni mencerdaskan kehidupan bangsa sekaligus menegaskan ideologi Pancasila sebagai ideologi bangsa. PTKIN harus mampu menerjemahkan nilai universal Islam dan Pancasila, tanpa adanya pertentangan diantaranya. Pada saat yang bersamaan, Pendidikan Kewarganegaraan yang ada di dalamnya tidak harus dimaknai sebagai ruang doktriner, melainkan ruang dialogis yang mempertemukan antara nilai-nilai universal-yang termanifestasikan dalam teori maupun dalil hukum - dengan berbagai peristiwa yang riil. Secara komparatif juga akan mendeskripsikan bagaimana pendidikan model stick and carrot justru akan menjauhkan dari tujuan pembelajarannya, hanya menciptakan ketakutan, dan tidak berbeda dengan pola konstruksi radikalisme. Sebagai penyimpul, Pendidikan terintegratif melibatkan kreasi terhadap produk-produk ilmiah multidisiplin, khususnya produk yang dihasilkan PTKIN, sebagaimana materi yang diadopsi dari kajian Pendidikan Islam. Harapan dengan model pendidikan tersebut, terbentuk pemahaman holistik pebelajar, sehingga dengan daya kritis yang dimiliki, secara mandiri akan mampu menganalisis bahaya radikalisme bagi eksistensi Negara Republik Indonesia.

Kata Kunci: Pendidikan Kewarganegaraan, PTKIN, Pendidikan Terintegratif.

\section{A. PENDAHULUAN}

Dewasa ini Pancasila kembali dihadapkan pada uji kelayakan sebagai ruh bangsa dan Negara Kesatuan Republik Indonesia (NKRI). Terlebih lagi di era media digital ini, pandangan masyarakat sebagai warga negara terhadapnya dapat menjadi lebih kompleks. Kemudahan untuk memperoleh informasi, tidak selamanya memberikan pemahaman yang memadai. Hal tersebut menjadi tantangan serius terhadap desain pendidikan ideologi, sehingga diharapkan mampu menjawab kompleksitas yang dihadirkan teknologi informasi dan komunikasi tersebut.

Berbagai macam pendapat dan pertanyaan diajukan, bahkan belakangan ini semakin sporadis. Muncul di berbagai media sosial seolah mempertanyakan kembali eksistensinya; "apakah Pancasila masih relevan menjadi pilar utama kebangsaan Indonesia?" Sebagaimana pendapat yang diajukan oleh budayawan Sujiwo Tejo1,

\footnotetext{
1 Sujiwo Tejo memiliki nama asli Agus Hadi Sujiwo. Budayawan kontemporer kelahiran Jember 31 Agustus 1962 tersebut mengawali kiprah seni di bidang pewayangan, kemudian merambah ke bidangbidang lain, seperti teater, sastra, dan film. Banyak karya fenomenal yang telah dipublikasikan, hingga kini tidak hanya tampil sebagai budayawan kritis tetapi juga menjadi influencer di media sosial dengan jargon "djantjoek", "jancuk", dan basis pengikutnya disebut sebagai "jancukers" (dikutip dari www.sujiwotejo.net/profile, diakses pada 29 April 2020).
} 
JRTIE: Journal of Research and Thought of Islamic Education

Vol. 3, No. 1, 2020

Pancasila merupakan suatu ontologi nisbi, sebagai sebuah nilai yang tidak pernah muncul dalam kehidupan keseharian². Perlu diketahui, selain dikenal sebagai budayawan, Sujiwo Tejo juga merupakan seorang influencer ${ }^{3}$, sehingga pendapatnya di dunia media kontemporer selalu menarik untuk diikuti khalayak.

Di pihak lain, banyak kalangan akademisi yang mempertanyakan kembali eksistensi Pancasila sebagai ideologi negara. Seperti halnya pernyataan Rocky Gerung4-seorang influencer lainnya-yang dinyatakan dalam salah satu acara televisi swasta nasional, Indonesian Lawyers Club (ILC), bahwa Pancasila bukanlah suatu ideologi negara, melainkan dasar negara-oleh karena eksistensi negara bukanlah subjek berkesadaran yang memiliki ideologi. Lanjutnya, dalam sejarah hanya negara-negara berhaluan komunis yang memiliki ideologi.

Tentu saja artikel ini tidak dimaksudkan secara khusus membahas pertanyaan maupun pernyataan tersebut, meski narasi tersebut cukup menarik untuk diletakkan sebagai pengantar. Artikel ini secara khusus akan membahas pendidikan ideologi, mengacu pada konstruksi ideologi bangsa dan negara, yakni Pancasila, dan relasinya terhadap konstruksi ideologi lain yang bersifat paradoks terhadapnya, sebagaimana radikalisme dan terorisme. Dalam pembahasannya, artikel akan mencoba mendeskripsikan, suatu konstruk ideologi yang dapat terjadi secara alamiah, dan tetap akan terbentuk meski tanpa desain yang memadai. Terlebih media digital telah memberikan sentuhan epistemologi yang unik, mengacu pada kepada kemudahan akses pengetahuan dan kemerdekaan terhadap interpretasi wacana.

Artikel akan memberikan tawaran objek formal berupa pendidikan terintegratif yang melekat dalam Mata Kuliah Wajib Umum (MKWU) Kewarganegaraan, terutama di PTKIN. Hal tersebut menjadi penting untuk dipahami, karena selain ditunjuk oleh

${ }^{2}$ Dalam beberapa kesempatan lain, Sujiwo Tejo memberikan pandangan sebagai clue jawaban atas pertanyaannya sendiri, bahwa Pancasila bukan lah suatu konsep pengertian yang harus dihafal, melainkan suatu tata nilai yang seharusnya melebur dalam diri anak bangsa, sehingga hal tersebut bertransformasi menjadi suatu kesadaran individu, melandasi setiap gerak individu tersebut, hingga secara masif mengikatkan diri dalam suatu kodifikasi kesadaran dalam komunitas kebangsaan.

${ }^{3}$ Bahasa yang lazim digunakan oleh masyarakat media sosial untuk menunjukkan persona yang berpengaruh, dan memiliki pengikut dalam jumlah relatif besar.

${ }^{4}$ Pernah tercatat sebagai staf pengajar metodologi filsafat di Universitas Indonesia. 
Undang-Undang sebagai salah satu wahana utama terhadap pendidikan ideologi di Indonesia, MKWU tersebut tengah berada dalam situasi penuh tekanan, muncul dari gelombang epistemologi pengetahuan acak, sebagai bentuk polusi intelektual yang dihasilkan dinamika komunikasi media sosial. Oleh karenanya, desain pembelajaran harus disusun secara tepat, sehingga hasil pembelajaran dapat memperkuat ikatan hubungan antara negara dengan warganya oleh kesemestaan utuh; baik dalam perspektif identitas, maupun tujuan kolektifnya.

Memilih PTKIN sebagai objek material, bukan tanpa alasan. Dewasa ini radikalisme dan terorisme sering dilekatkan pada identitas Islam. Tentu saja persandingan diantara keduanya tidak dapat diterima. PTKIN sebagai ruang produksi pengetahuan ilmiah-terutama dalam kajian-kajian keislaman-harus mampu menghasilkan produk-produk ilmiah yang menunjukkan bahwa Islam merupakan ontologi nilai yang berbeda sama sekali dengan apa yang telah ditunjukkan oleh kaum radikalis. Terlebih, Islam merupakan kesemestaan nilai yang menjiwai Pancasila, sebagai rujukan warga negara untuk membentuk tata sosial madani dan beradab. Adapun hasil yang diharapkan dari kolaborasi antara Pendidikan kewarganegaraan dengan keberadaan PTKIN adalah pemahaman holistik yang disaripatikan dari hasil kajian diantara keduanya. Pemahaman tersebut diharapkan mampu menjadi filter bagi warga negara dari gempuran epistemologi acak dan konstruk ideologi anti Pancasila.

Kembali kepada narasi pengantar di atas, terlepas dari bangunan logika maupun seni retorika, apa yang menarik untuk diajukan adalah tentang makna ideologi itu sendiri. Istilah ideologi berasal dari etimologi Yunani "idea" yang memiliki arti "gagasan", "konsep", "pengertian dasar", atau dari "eidos" bermakna "bentuk" dan petanda epistemologisnya terbentuk dari kata "logos" berarti "ilmu". Selanjutnya ideologi memiliki makna terminologis dan konteks realitas kesehariannya. Secara terminologis, ideologi disebut sebagai ilmu tentang pengertian-pengertian dasar, sedangkan secara realitas keseharian dapat diletakkan sebagai cita-cita yang terwujud dari gagasan dasar. Gottfried W. Leibniz, seorang filsuf theodicee Jerman mengungkap bahwa ide atas cita-cita merupakan bentuk "one great system of truth", yakni tidak hanya 
JRTIE: Journal of Research and Thought of Islamic Education

Vol. 3, No. 1, 2020

membahas khayalan imajinatif melainkan merupakan keterpaduan sistemik dari kebenaran. Dalam ruang dan waktu yang terpisah, filsuf Perancis A. Destutt de Tracy menyebut "ideologie" sebagai "science of ideas", merujuk pada suatu program yang diharapkan menciptakan perubahan institusional dalam masyarakat. ${ }^{5}$

Dalam konteks keindonesiaan, ideologi bukan merupakan hasil imajinasi semu, dapat dilihat dalam perjuangan kemerdekaan Indonesia dari cengkraman kolonialisme. Perasaan senasib dan sepenanggungan dari ketertindasan kolonialisme membentuk suatu mitos identitas kebangsaaan, dan menggerakkan segenap kesadaran kolektif dalam rangkaian aksi revolusi kemerdekaan, melebur pada identitas bersama, disebut dengan bangsa Indonesia. Bahkan dalam konteks idologi, kolonialisme itu sendiri juga merupakan aksi dari penjabaran ide lebensraum ${ }^{6}$, sehingga dalam hal ini dapat ditarik sebuah kesimpulan, ideologi merupakan penentu dari dinamika aksi yang dilakukan oleh manusia, baik secara personal maupun kolektif.

Pernyataan Rocky Gerung sebagaimana dimunculkan sebagai pengantar di atas, juga tidak dapat sepenuhnya diafirmasi, bahwa ideologi hanya diletakkan kepada kepemilikan subjek terbatas, individu-personal maupun negara tertentu saja. Ideologi dapat diletakkan sebagai kristalisasi pengetahuan manusia yang selanjutnya digunakan dengan teliti untuk meraih cita-cita tertentu. Adapun ideologi dalam konteks kolektif dalam arti negara, termasuk ideologi bangsa dan negara Indonesia yang disebut dengan Pancasila, merupakan hasil kontemplasi para founding fathers dari saripati realitas kebangsaan untuk mewujudkan cita-cita nasional. Demikian, Pancasila yang diletakkan sebagai dasar negara (state fundamental norm), memiliki arti bahwa hal tersebut merupakan bentuk manifestasi ideologi kolektif-komunal yang disepakati sebagai kontrak sosial dalam kehidupan kenegaraan, dan diatur dalam konstitusi UndangUndang Dasar Negara Republik Indonesia Tahun 1945.

${ }^{5}$ Kaelan, Pendidikan Kewarganegaraan Untuk Perguruan Tinggi (Yogyakarta: Paradigma, 2016), hlm. 179.

${ }^{6}$ Mengacu pada istilah "ruang hidup" yang mendasari konsep geopolitik modern. Diperkenalkan oleh Friedrich Ratzel yang berpandangan bahwa negara selayaknya organisme yang lahir, hidup, dan berkembang, bahkan mati. Oleh sebab itu, negara juga diimajinasikan membutuhkan ruang makan, dengan cara menolak batas negara itu sendiri, baik berbentuk kolonialisasi maupun aneksasi. 
Menjadi suatu yang layak diperhatikan, bagaimana akademisi dan cendekiawan muda apatis terhadap Pancasila sebagai ideologi bangsa. Terlebih kaum milenial7 yang sangat lekat dengan teknologi informasi dan komunikasi, dapat dengan mudah mengunduh suatu pengetahuan, dan kecenderungan terhadapnya dikelola secara secara pragmatis, hanya mengafirmasi tawaran aplikatif di dalamnya, tanpa mempertimbangkan berbagai potensi dinamikanya. Kondisi tersebut tidak lah sertamerta dapat dikatakan sebagai suatu hal yang ideal. Bagaimanapun juga ideologi merupakan suatu nilai panduan yang dapat mengarahkan kepada realitas masa depan yang lebih baik, sesuai dengan cita-cita nasional.

Keresahan terhadapnya muncul bersamaan dengan minimnya minat dan kepedulian kalangan muda tersebut terhadap disiplin kajian kewarganegaraan, dan rumpunnya. Pendidikan Kewarganegaraan pada dasarnya merupakan media untuk dapat menransformasikan ide besar negara sebagaimana tersusun dalam konstitusi kepada setiap warga negara Indonesia, melalui pebelajar atau peserta didik di lingkungan pendidikan. Hanya saja pendidikan tersebut lebih banyak dinilai sebagai syarat kepatuhan, bukan dimaknai sebagai persiapan peserta didik dalam menghadapi tantangan kehidupan sebagai warga negara yang kompleks.

Keresahan tersebut diperkuat oleh penelitian yang dilakukan oleh Pusat Studi Pancasila Universitas Gadjah Mada, terutama di lingkungan pendidikan dasar dan menengah. Peserta didik menunjukkan antusiasme yang rendah terhadap Pendidikan Pancasila dan Kewarganegaraan. Alasan klasik yang melatarbelakanginya lebih kepada program PPKn tidak dimasukkan ke dalam kerangka penilaian ujian nasional. ${ }^{8}$

Pembiaran pandangan masyarakat - khususnya peserta didik - terhadap program Pendidikan Kewarganegaraan akan berbahaya terhadap kehidupan bangsa dan negara. Artinya, Pendidikan Kewarganegaraan harus berbenah ulang: tidak dapat dipandang lagi sebagai pendidikan doktriner yang menjemukan. Selama ini model pendidikan

7 Parole, penyebutan untuk "kaum muda", "pemuda", maupun "anak muda" di era kontemporer.

8 Muthmainnah, Muhaimin, dan Widodo, "Integrasi ESD dalam Pembelajaran dan Penguatan Metodologi Keilmuan Pancasila bagi Guru di Kawasan Bantul Selatan", Indonesian Journal of Community Engagement Vol. 02, No. 01, September 2016, hlm. 32-52. 
dalam kajian tersebut - termasuk pembelajarannya - lebih dikenal sebagai penghafalan atas klausa moral. Vis a vis dengan perkembangan zaman yang memberikan wahana adrenalin bagi kaum muda. Model pendidikan dalam kajian tersebut harus berevolusi menjadi sama menariknya dengan apa yang ditawarkan oleh zaman. Pendidikan Kewarganegaraan harus mempertemukan antara nilai ideologi yang dibawa kepada realitas kehidupan kontemporer. Materi integratif dengan konten dari berbagai disiplin ilmu dapat diramu dengan meretas model pembelajaran hybrid learning.

Menggarisbawahi lagi, era digital akan menyisakan residu destruktif apabila tidak didukung dengan sistem pendidikan yang mampu menjelma sebagai filter pengetahuan yang dihasilkan oleh media tanpa menyantumkan catatan kaki. Alih-alih kemudahan terhadap akses informasi menyediakan pengetahuan memadai-termasuk didalamnya pemahaman terhadap Pancasila - justru tanpa disadari, digitalisasi informasi yang beredar tanpa kawalan akan membentuk pengetahuan tandingan-lembaga pendidikan formal-yang bersifat subjektif, stigmatis, dan dogmatis. Ironisnya pengetahuan tersebut terbentuk oleh prasangka personal maupun kelompok yang pada akhirnya bermuara kepada kebenaran tunggal bermakna peyoratif.

Sementara itu, pendidikan ideologi dalam sudut pandang alamiah, bukan merupakan suatu eksisten stagnan, sebaliknya berkembang sesuai dengan peredaran zaman. Dalam kajian kewarganegaraan, dapat dilihat bagaimana perkembangan angka radikalisme dunia - khususnya Indonesia - berkembang melalui andil media teknologi komunikasi dan informasi. Penelitian Gabriel Weimann ${ }^{9}$ menunjukkan bahwa pada tahun 1998 hanya terdapat 12 situs dikelola oleh radikalis-teroris, kemudian meningkat mencapai 2.650 situs pada tahun 2003, dan terus berkembang hingga 9.800 situs pada tahun 2014. Di Indonesia sendiri, berdasarkan survei dilakukan oleh Badan Nasional Penanggulangan Terorisme (BNPT) ${ }^{10}$, selama April hingga Juli 2019, diperoleh skor sebesar 38,22 (skala 0 - 100) dalam Indeks Diseminiasi Media Sosial atau penyebaran

\footnotetext{
9 Imam Ghifari, "Radikalisme di Internet", Jurnal Agama dan Lintas Budaya Vol. I, No. 1, Maret 2017, hlm. 123-134.

10 Febryan A., "Radikalisme di Medsos, BNPT Petakan 4 Konten Keagamaan", Media Republika online (11 Desember 2019), https://m.republika.com/amp/q2b4os428 diakses pada 20 April 2020.
} 
konten yang memicu radikalisme. Tentu saja hal tersebut merupakan kondisi yang mengkhawatirkan.

Berbagai fakta ilmiah tersebut dapat ditarik suatu benang merah bahwa ideologi merupakan hal mendasar bagi kehidupan masyarakat. Radikalisme dan terorisme merupakan bagian tidak terpisahkan sebagai hasil proses transformasi ideologi. Berdasarkan relasi-relasi tersebut, maka artikel jurnal ini bermaksud untuk mengajukan kembali arti Pendidikan Kewarganegaraan sebagai pengantar ideologi secara ilmiah, terutama di Perguruan Tinggi Keagamaan Islam Negeri (PTKIN) yang memiliki peran besar-sebagai kepanjangan tangan pemerintah dalam upaya transformasi ideologi Pancasila di bidang pendidikan dan keagamaan populer masyarakat.

Untuk kepentingan keteraturan pemahaman, maka dapat diletakkan pandangan terhadap Pendidikan Kewarganegaraan dan PTKIN sebagai dua subjek otonom, meski tetap terikat dalam pandangan ideologi yang selaras, yakni berdasarkan Pancasila. Penelitian ini menggunakan penelitian deskriptif-kontemplatif, dengan model studi kepustakaan melibatkan fakta ilmiah yang telah berhasil dicatat. Untuk memudahkan alur artikel, maka diajukan setidaknya tiga rumusan masalah, sehingga pembacaan terhadapnya dapat koheren dan utuh. Adapun rumusan tersebut meliputi: (i) urgensi Pendidikan Kewarganegaraan di PTKIN; (ii) peran PTKIN terhadap transformasi ideologi; dan (iii) model pendidikan terintegratif dalam Pendidikan Kewarganegaraan sebagai upaya transformasi ideologi. Harapan dan tujuan utama dari artikel jurnal ini adalah lebih kepada upaya konstruktif terhadap pemahaman yang utuh, antara pergerakan ideologi dan pendidikan, sehingga masyarakat luas melalui peserta didik di PTKIN dapat mengunduh keluhuran Pancasila sebagai Ideologi bangsa dan negara.

\section{B. URGENSI PENDIDIKAN KEWARGANEGARAAN DI PTKIN}

Pancasila dan Kewarganegaraan termasuk rumpun MKWU, sebagaimana termuat dalam UU No. 12 Tahun 2012 tentang Pendidikan Tinggi, Pasal 35 Ayat 3 -menyatakan bahwa Mata Kuliah Agama, Pancasila, Pendidikan Kewarganegaraan, dan Bahasa indonesia merupakan mata kuliah wajib yang harus diajarkan di seluruh perguruan tinggi, tidak terkecuali PTKIN. Tentu saja pelaksanaan UU tersebut tidak dilakukan 
JRTIE: Journal of Research and Thought of Islamic Education

Vol. 3, No. 1, 2020

sebagai wujud "gugur kewajiban" saja, artinya sekedar pemenuhan terhadap nomenklatur, sehingga penyelenggaraan pendidikan perguruan tinggi dapat terpenuhi pada aspek nota hukumnya.

Amanah konstitusi menjelaskan bahwa pemerintah wajib ikut andil dalam upaya pembentukan karakter anak bangsa, yakni dengan mewajibkan kelompok mata kuliah pengembangan kepribadian untuk dapat disampaikan di seluruh Perguruan Tinggi di Indonesia. Disarikan dalam Kaelan, ${ }^{11}$ setidaknya menurut Keputusan Dirjen Pendidikan Tinggi No. 43/DIKTI/KEP/2006 melibatkan pokok-pokok bahasan meliputi: (i) Filsafat Pancasila; (ii) Identitas Nasional; (iii) Negara dan Konstitusi; (iv) Demokrasi Indonesia; (v) Rule of Law dan Hak Asasi Manusia (HAM); (vi) Hak dan Kewajiban Warga Negara serta Negara (kausalitas); (g) Geopolitik Indonesia; dan (h) Geostrategi Indonesia.

Pada kenyataannya Indonesia memang bukan lah negara sekuler, yakni negara yang memisahkan diri antara urusan geopolitik dengan agama, bukan juga merupakan negara agama berkonstitusikan hukum dalam kaidah agama. Dalam perspektif kewarganegaraan, hubungan antara warga negara dengan negaranya dapat ditelisik dari dua perspektif penting, yakni sebagai bentuk masyarakat dalam perspektif gejala hukum, dan perspektif berikutnya adalah entitas warga negara, yakni manusia sebagai makhluk Tuhan. Perspektif terakhir tersebut mengejawantahkan bahwa manusia memiliki kedudukan dan hubungannya sendiri yang unik, secara horisontal merujuk hubungan individu dengan kelompoknya, disebut sebagai komunitas atau masyarakat, dan secara vertikal berhubungan terhadap Tuhan yang mengkhalikkannya. ${ }^{12}$

Dalam perspektif ideologi pendidikan Indonesia, pola pendidikan merujuk pada dua hal penting, melibatkan dua subjek bidang yakni kewarganegaraan dan agama. Sebagaimana diatur oleh konstitusi UUD 1945, pasal 31 ayat 5, menjelaskan bahwa “Pemerintah memajukan ilmu pengetahuan dan teknologi dengan menjunjung tinggi nilai-nilai agama dan persatuan bangsa untuk kemajuan serta kesejahteraan umat manusia." Bersamaan dengan upaya memajukan pendidikan, dalam Pasal 32 ayat 1

\footnotetext{
${ }^{11}$ Kaelan, Pendidikan Kewarganegaraan..., hlm. 4.

12 Darmodiharjo, Darji et.al. Santiaji Pancasila (Surabaya: Usaha Nasional, 1991), hlm. 215.
} 
menjelaskan bagaimana negara memajukan kebudayaan nasional Indonesia di tengahtengah peradaban dunia, dengan penjaminan terhadap masyarakat pemangku dalam mengembangkan nilai-nilai budayanya.13 Dua pasal dalam UUD 1945 tersebut, secara kausal mendeskripsikan bahwa tidak terdapat garis pemisah antara upaya pendidikan nasional yang menghasilkan produk teknologi tepat guna dengan produk sikap-moral yang diproyeksikan menjadi adjektiva "moral good" melekati warga negara, dimanifestasikan dalam segitiga pilar karakter konstitusi, agama, dan budaya lokal.

Dengan demikian, PTKIN maupun lembaga pendidikan keagamaan lain, merupakan episentrum transformasi ideologi. Kajian keislaman secara epistemologis berasal dari kebenaran yang dibawa oleh ideologi keagaman Islam, meskipun empirisme dan positivisme saling memberikan warna di dalamnya. Di sisi lain, sosietas masyarakat merupakan suatu bangunan kompleks, melibatkan interaksi antar budaya, baik dalam lingkup antar budaya nasional, atau bahkan dalam kancah pergaulan internasional. Kerangka berpikir tersebut seyogyanya menjadi nota perhatian, pendidikan merupakan salah satu wahana konstruktif atas bangunan ideologi. Penyusunan baik dalam kacamata kurikulum maupun materi ajar-terutama pada rumpun ilmu sosio-humaniora-dilandaskan pada konsep multikulturalisme, dan diracik dalam suatu konsep terintegratif.

Pada titik tawar multikultural tersebut lah, Pendidikan Kewarganegaraan menjadi penting. Pendidikan Kewarganegaraan memiliki peran sebagai jembatan terhadap pertemuan beberapa nilai yang bersifat universal, khususnya nilai Islam dan kebangsaan Indonesia. Titik tawar dapat ditelisik melalui visi, misi dan kompetensi Pendidikan Kewarganegaraan dalam Keputusan Dirjen Dikti No. 43/Dikti/Kep/2006 meliputi, visi: “Sumber nilai dan pedoman dalam pengembangan dan penyelenggaraan program studi, guna mengantarkan mahasiswa memantapkan kepribadiannya sebagai manusia seutuhmya. Hal ini berdasarkan pada suatu realitas yang dihadapi, bahwa mahasiswa adalah sebagai generasi bangsa yang harus memiliki visi intelektual,

13 Tim Penyusun Kemenristekdikti, Pendidikan Pancasila Untuk Perguruan Tinggi (Jakarta: Direktorat Jendral Pembelajaran dan Kemahasiswaan, 2016), hlm.108. 
JRTIE: Journal of Research and Thought of Islamic Education

Vol. 3, No. 1, 2020

religius, berkeadaban, berkemanusiaan, cinta tanah air dan bangsanya"; dan misi: "Pendidikan Kewarganegaraan di perguruan tinggi adalah untuk membantu mahasiswa memantapkan kepribadiannya, agar secara konsisten mampu mewujudkan nilai-nilai dasar Pancasila, rasa kebangsaan dan cinta tanah air dalam menguasai, menerapkan, dan mengembangkan ilmu pengetahuan, teknologi dan seni dengan rasa tanggung jawab". ${ }^{14}$ Apa yang menjadi tujuan pembelajarannya sebagaimana termuat dalam visi dan misi mata kuliah, dan dipedomani pada Peraturan Menteri Riset Teknologi dan Perguruan Tinggi Republik Indonesia No. 44, Tahun 2015 tentang Standar Nasional Perguruan Tinggi, jarang diperhatikan. Secara lebih gamblang, wujud peraturan tersebut diarahkan pada konstruksi Kerangka Kualifikasi Nasional Indonesia (KKNI), sehingga peta hulu-hilir pembelajaran dapat dipertanggungjawabkan. Adapun kompetensi, yakni: "kompetensi yang diharapkan mahasiswa adalah untuk menjadi ilmuwan dan profesional yang memiliki rasa kebangsaan, cinta tanah air, demokratis, berkeadaban. Selain itu kompetensi yang diharapkan agar mahasiswa menjadi warganegara yang memiliki daya saing, berdisiplin, berpartisipasi aktif dalam membangun kehidupan yang damai berdasarkan sistem nilai Pancasila". ${ }^{15}$

Menariknya, Pendidikan Kewarganegaraan bersifat wajib untuk diajarkan, tetapi secara konten hanya dipandang sebelah mata. Tidak hanya diajarkan di tingkat perguruan tinggi, materi yang berkaitan dengannya telah diajarkan dari bangku sekolah dasar. Stigma tidak jauh dari pandangan atas model pendidikan doktriner, penghafalan terhadap klausa moral. Dapat dimengerti bagaimana stigma tersebut dapat mengakar di alam pikiran akademisi. Pendidikan Kewarganegaraan seringkali dibenturkan dengan model stick and carrot $^{16}$. Peserta didik lebih diletakkan sebagai subjek pasif, menerima segala doktrin negara bersifat komando, tanpa diberikan ruang dialog kepadanya.

${ }^{14}$ Kaelan, Pendidikan Kewarganegaraan..., hlm. 2.

${ }^{15}$ Kaelan, Pendidikan Kewarganegaraan..., hlm. 2.

16 Pendidikan yang didasarkan pada hukuman dan hadiah. Dalam konteks tertentu, pendidikan tersebut akan menghukum siapa saja termasuk kepada individu maupun kelompok yang tidak menjalankannya - dalam bentuk ritus. Tetapi hadiah yang ditawarkan bagi subjek pelaksana, tidak lebih dari hak dasar yang seharusnya diberikan. Sebagai ilustrasi, lumba-lumba di arena sirkus akan mendapatkan hukuman dari pelatihnya jika melakukan kesalahan, tetapi akan mendapatkan hadiah berupa makanan pokoknya jika hewan tersebut melakukan semua yang diinstruksikan pelatih. 
JRTIE: Journal of Research and Thought of Islamic Education

Vol. 3, No. 1, 2020

Dari penelusuran temporal, mengacu pada era Orde Baru, peneguhan ideologi Pancasila secara eksplisit dieksekusi melalui Ketetapan Majelis Permusyawaratan Rakyat Nomor II/MPR/1978, tentang Pedoman Penghayatan dan Pengamalan Pancasila (P-4), atau disebut dengan Ekaprasetya Pancakarsa. Dalam kasus lebih unik, Ekaprasetya Pancakarsa tersebut menjadi rujukan pedoman kehidupan beragama, sebagaimana diterbitkannya Buku Pedoman Pelaksanaan P-4 bagi Umat Islam, sesuai dengan Ketetapan MPR/II/3. Dalih penerbitan buku pedoman tersebut adalah pemantapan ideologis pembangunan nasional, sekaligus memperteguh ketiadaan pertentangan atas fitrah manusia sebagai warga negara sekaligus sebagai umat pemeluk agama. Dualitas kewajiban yakni penghayatan dan pengamalan Pancasila sebagai warga negara dan mengamalkan ajaran agama sebagai umat beragama dapat dijalankan secara penuh, sinergis, dalam rangka menjamin stabilitas keamanan nasional, dan bermuara pada stabilitas kehidupan-pembangunan nasional. ${ }^{17}$

Hal tersebut dapat dimengerti saat konsep ketahanan nasional diletakkan sebagai doktrin negara. Doktrin dalam pemahaman tertentu diletakkan sebagai konsep pemaksa terhadap ketaatan pemikiran masyarakat tertentu untuk dapat berjalan sesuai dengan aturannya. Meskipun demikian, doktrin yang mengontrol sepenuhnya pemikiran masyarakat tanpa daya kritis mumpuni, justru menimbulkan efek kontra produktif vis a vis dengan tujuan yang telah ditetapkan. Bagaimanapun juga doktrintermasuk dalam hal ini doktrin negara-harus senantiasa di evaluasi secara berkelanjutan dengan berbagai fakta dan peristiwa yang mewarnai realitas kehidupan kontemporer. Pada kenyataannya, doktrin berbeda dengan nilai, di mana nilai bersifat universal sedangkan doktrin merupakan hasil kajian terhadap nilai tersebut. Dalam hal ini dapat disimpulkan bahwa doktrin merupakan suatu kebenaran yang bersifat tentatif berdasarkan perkembangan ketelitian ilmu pengetahuan. Berbeda dengan nilai, meminjam pemahaman CA. Van Peursen, ${ }^{18}$ nilai tidak bersifat tentatif dan tidak harus

17 Departemen Agama Republik Indonesia, Pedoman Pelaksanaan P-4 Bagi Umat Islam (Jakarta: Proyek Bimbingan Pelaksanaan P-4 Bagi Umat Beragama, 1983), hlm. 2-3.

${ }_{18}$ Van Peursen, Cornelis A., Fakta, Nilai, Peristiwa: Tentang Hubungan Antara Ilmu Pengetahuan dan Etika (Jakarta: Gramedia, 1992). 
berkesesuaian dengan fakta, maupun peristiwa. Nilai secara fungsional merupakan guidance bagi perilaku kehidupan sehingga ketidakmampuan daya serap terhadapnya akan menimbulkan realitas fakta maupun peristiwa yang berbeda.

Dalam perspektif pendidikan model tersebut, tentu saja menjadi kontra produktif jika harus disandingkan dengan tujuannya, yakni menjadi pintu gerbang transformatif bagi peserta didik atau pebelajar dalam kehidupan riil. Paulo Freire, ${ }^{19}$ memberi gambaran bahwa pendidikan merupakan suatu kegiatan produksi kesadaran manusia bersifat keping mata uang. Disebutkannya pendidikan konvensional-sebagai sisi pertama-merupakan suatu wahana imajiner yang membentuk kesadaran manusia dalam bingkai dogmatis, menempatkan manusia sebagai objek, penuh ketakutan, dan patuh terhadap simbol kekuasaan secara sempit, hanya menempatkan murid sebagai "bank" segala pengetahuan yang diberikan guru. Sisi sebaliknya, disebut dengan "pendidikan membebaskan", merupakan bentuk perlawanan dari segala bentuk tekanan dan paksaan, menempatkan manusia sebagai subjek dengan membangun kesadaran kritis. Artinya adalah pendidikan tersebut membukakan mata manusia dalam ragam yang kaya, persinggungan antara alam sadar dengan semesta realitas. Oleh karena pandangan tersebut, menjadi penting dalam Pendidikan Kewarganegaraan di PTKIN menempatkan Pancasila dan Islam tidak saja dipandang sebagai kesepakatan bersama antar subjek pendiri bangsa, atau antar penganutnya. Lebih urgen untuk ditempatkan sebagai nilai ideologis bangsa yang seharusnya menggerakkan tata kehidupan bangsa, dari hulu menuju hilir, dari input, proses, hingga output suatu dinamika sosiokultural.

Dalam konteks Pendidikan Kewarganegaraan di PTKIN, materi kajian di dalamnya harus mampu menawarkan suatu konsep terpadu sesuai dengan konstruksi KKNI, menitikberatkan pada konsep capaian lulusan (CPL), secara terstruktur senantiasa dievaluasi dari sasaran capaian, materi pembelajaran, ruang praktik, dan capaian lulusan berdasarkan bidang ilmu masing-masing program studi (Prodi) di PTKIN. Tujuannya adalah bagaimana nilai-nilai staat fundametal norm bangsa ini dapat

${ }_{19}$ Paulo Freire, Pendidikan Kaum Tertindas (Jakarta: LP3S, 2011), hlm: 54-56. 
JRTIE: Journal of Research and Thought of Islamic Education

Vol. 3, No. 1, 2020

diaplikasikan dalam bidang yang luas, bersifat tematik, dan akan terkodifikasi pengetahuan utuh yang menjiwai (geisteswissencaften) warga negara Indonesia, tanpa harus bertentangan dengan nilai luhur yang telah bersemayam di tubuh Islam, sehingga apa yang menjadi cita-cita dan tujuan nasional dapat terjangkau.

\section{PERAN PTKIN DALAM DERADIKALISASI DAN PENEGAS IDEOLOGI PANCASILA}

Dewasa ini, agama-terlebih Islam-seringkali diidentifikasikan sebagai suatu paham yang keras, rigid, dan anti toleran sehingga dalam kadar tertentu disrupsi pengetahuan tersebut akan memberikan ekses negatif bagi persatuan bangsa. Peperangan jastifikasi kebenaran dengan melibatkan tafsir terhadap alam pikiran Islam terus merebak di dunia media sosial, secara liar dan membabi buta sehingga menciptakan wahana perdebatan cenderung tidak sehat, dan menuju perpecahan bangsa. Salah satu upaya untuk menetralisir hal tersebut adalah bagaimana merekonstruksi pandangan ideologis tentang Islam itu sendiri melalui investasi pendidikan, terutama untuk menguak peran PTKIN.

Hal penting yang perlu digarisbawahi adalah bagaimana mendekonstruksi pemahaman masyarakat, bahwa aktor dibalik kegiatan antitoleran tersebut bukan lah Islam yang sebagai nilai, melainkan paham atau pandangan kelompok (-isme) yang berbalut ideologi agama. Fenomena tersebut ditangkap baik oleh Sudjito, Hendro Muhaimin, dan A. Saras Sri Widodo,20 yang menyebutkan bahwa dalam Bahasa Arab, radikalisme dapat diidentifikasi dari berbagai istilah, sebagaimana "al-unf", "al-tatarruf", "al-guluww". "Al-unf" merupakan aksi kekerasan oleh gerakan yang melawan hukum (kejahatan) untuk memaksakan hasrat seseorang maupun kelompok tertentu, sedangkan "al-tatarruf" berasal dari etimologi "al-tarf" yang berarti "ujung" atau "tepi", meliputi tepi kiri atau kanan. Oleh karena itu, kata tersebut berarti radikal, ekstrim, dan berlebihan. Demikian, "al-tarraruf" dalam konsep "al-dini" merupakan sesuatu hal yang bersifat tertutup sebagai bentuk antonim dari "al-wasath" (tengah atau moderat)."

20 Sudjito, Muhaimin, dan Widodo, "Pancasila and Radicalism: Pancasila Enculturation Strategies as Radical Movements Prevention", Jurnal Dinamika Hukum, Vol. 18, No. 1, Januari 2018, hlm. 69-70. 
Berangkat dari pengantar arti terminologis tersebut, pengembangan wacana dapat diarahkan bagaimana radikalisme tersebut menggurita pada alam pikiran masyarakat. Terbentuknya gagasan imoderat sebagaimana dalam deskripsi tersebut, sesungguhnya merupakan realitas terpisah dari tubuh Islam. Pemahaman konsep Islam "utuh" (kaffah) yang seringkali digunakan kelompok tertentu untuk melegalisasi tindakan kekerasan, lebih menunjukkan fenomena politik berbalut agama, bukan esensi dari agama itu sendiri. Pada dasarnya beberapa terminologi yang digunakan para ekstrimis untuk melegalisasi tindakannya memang diambil dari teks kitab suci, sebagaimana penyebutan "kafir", "jihad", dan istilah lainnya dapat ditemui dalam As-Sunah maupun Al-Quran. Hanya saja pemaknaan terhadapnya cenderung subjektif, didasarkan pada penghasratan subjek penggunanya. ${ }^{21}$

Radikalisme dan terorisme dalam konteks tersebut dapat dijelaskan sebagai konstruksi ideologi, yakni bagaimana pemahaman kelompok diarahkan oleh individu atau kelompok lebih kecil di dalamnya dengan muatan tujuan tertentu, disesuaikan oleh kepentingan tertentu pula. Setiap aksi memiliki motif kepentingan yang melatarbelakanginya, baik secara personal (personal interest) maupun komunitas (community interest). Tanpa dapat dielakkan, manusia merupakan mahluk sosial yang membutuhkan tubuh sosial, bahkan tujuan komunal meski hanya sekedar untuk memenuhi kepentingan personalnya. Demikian dengan radikalisme dan terorisme, merupakan suatu gerakan kelompok yang membutuhkan tubuh sosial untuk mencapai tujuan sesuai dengan kepentingannya.

Pembentukan kelompok tersebut memerlukan suatu upaya yang dapat dipandang sebagai upaya strategis. Rekrutmen tidak dilakukan tanpa konsep memadai, desainnya mencerminkan campur tangan individu maupun kelompok terdidik dan terlatih. Tidak jarang pola konstruksi ideologis di dalamnya melibatkan dekonstruksi nilai yang terdapat dalam kitab suci, untuk selanjutnya ditransformasikan ke alam pikiran subjek maupun objek tertuju-baik individu maupun kelompok-sebagai bagian dari

${ }^{21}$ Sudjito, Muhaimin, dan Widodo, "Pancasila and Radicalism: Pancasila Enculturation Strategies as Radical Movements Prevention", Jurnal Dinamika Hukum, Vol. 18, No. 1, Januari 2018, hlm. 70-72. 
rangkaian pembentukan komunitas sosial bagian darinya. Dalam hal ini dapat dikatakan kelompok radikal-teroris tersebut menciptakan suatu bangunan pendidikan yang sistematis dan terstruktur sehingga secara efektif segala pengetahuan yang telah diproduksinya mampu menjelma menjadi dogma yang dapat diterima.

Indonesia, merupakan negara dengan penduduk Muslim terbesar dunia menjadikan potensi tujuan rekrutmen kelompok-kelompok radikal dengan mengatasnamakan ideologi Islam. Dikutip dari portal indonesia.go.id, ${ }^{22}$ penganut Islam di negara ini mencapai 87\% dari keseluruhan populasi, atau lebih dari 207 juta penganut. Latar belakang ideologi tersebut merupakan senjata efektif untuk mengikat individu atau kelompok untuk menjadi bagian yang sesuai dengan narasi radikalisme. Terlebih era kebebasan informasi menyediakan dualisme produksi pengetahuan, yakni pengetahuan yang bersifat bebas tanpa kawalan dan pengetahuan dengan catatan kaki. Berkembangnya teknologi informasi dan komunikasi memudahkan setiap orang untuk mempublikasi buah pikirannya, tanpa ada yang dapat menghalangi. Dapat dibayangkan bagaimana seseorang tanpa latar belakang pendidikan yang jelas atau dengan sengaja mendekonstruksi bangunan nilai tertentu dapat dengan mudah mempublikasikan buah pemikirannya. Sementara itu, di kesempatan lain orang dapat dengan mudahnya mengunduh pemikiran yang dilakukan secara arbitrer tersebut.

Berkaitan dengan hal tersebut, apa yang menarik adalah ketika angka radikalisme dan terorisme cenderung meningkat saat kebebasan interpretasi atas pengetahuan pada titik kulminasinya. Di Indonesia, era kepemimpinan Orde Baru dapat diletakkan untuk mewakili periode yang lebih konvensional, bagaimana teknologi informasi dan komunikasi tidak lebih canggih dibanding dengan perkembangan yang terjadi dewasa ini. Berbeda dengan era pasca gerakan reformasi tahun 1998, keleluasaan untuk menerima dan mengolah pengetahuan, kemudian menyatakan kembali pendapat sebagai reaksi sosialnya merupakan realitas kebebasan yang tampak mendominasi. Dalam hal ini tidak bermaksud untuk memperbandingkan rezim mana yang lebih baik, hanya untuk menunjukkan bagaimana perkawinan antara kebebasan dan teknologi

22 Data 2018, diakses April 2020. 
bukan hadir tanpa masalah, justru di dalamnya melahirkan pola disrupsi baru yang harus disikapi secara bijak.

Pola represif Orde Baru sebagaimana catatan sejarah telah menciptakan kultus terhadap militer (military heavy), sehingga suara kebebasan akan terganggu. Kultus tersebut memang bukan hal ideal, tetapi melahirkan penguatan dalam salah satu gatra geostrategi di bidang pertahanan dan keamanan. Hal tersebut dapat dilihat bagaimana minimnya aksi terorisme terjadi di era tersebut. Tercatat hanya 2 peristiwa teror besar yakni tahun 1981-pembajakan maskapai pesawat Garuda Indonesia yang terkenal sebagai teror DC-9 Woyla - dan tahun 1985-bom Candi Borobudur. Angka aksi teror menjadi membengkak mulai tahun 2000, puluhan teror tercatat dari peristiwa bom Kedubes Filipina, 1 Agustus 2000, hingga serangan Markas Kepolisian Daerah (Mapolda) Riau oleh Jamaah Ansharut Daullah (JAD) pada tanggal 16 Mei 2018.

Tentu saja hal tersebut bukan merupakan perbandingan memadai bagaimana penanganan terhadap terorisme. Menarik untuk diperhatikan, perkembangan terorisme di Indonesia tidak hanya didominasi oleh melemahnya sistem pertahanan dan keamanan dalam perspektif ketercukupan Alat Utama Sistem Pertahanan (Alutsista), infrastruktur keamanan, atau jumlah personel. Dinamika ideologi yang disumbangkan oleh kecepatan tranformasi pengetahuan oleh teknologi informasi merupakan penyebab signifikan terhadap melonjaknya gerakan terorisme di Indonesia. Pemangku kepentingan aksi teror sangat menyadari bagaimana teknologi komunikasi dan informasi memainkan peranannya dalam membentuk dinamika ideologi.

Hal tersebut tampak bagaimana kelompok-kelompok radikalis-teroris dalam menggunakan media sosial atau media teknologi komunikasi dan informasi sebagai instrumen propaganda, agitasi-dogmatis, dan rekrutmen anggota. Sebagaimana catatan Badan Penanggulangan Terorisme (BNPT) menunjukkan bahwa hingga Maret 2015, ISIS Indonesia menyumbang angka kontribusi hingga 20\% - 21.772 berbanding 112.075dari ISIS dunia terkait postingan berbentuk propaganda, agitasi, maupun ajakan bergabung menggunakan media Tweeter. 
JRTIE: Journal of Research and Thought of Islamic Education

Vol. 3, No. 1, 2020

Penelitian tentang transformasi radikalisme kepada terorisme menunjukkan berbagai simpulan gerak rekrutmen dengan pola pendidikan tidak dapat terdeteksi. Transformasi individu dari radikal ke teroris merupakan bentuk gerakan sosial tanpa adanya organisasi induk (decentralized), terpecah atau tercabang (segmentary), namun terjaring secara organisatoris tanpa induk (reticulated). ${ }^{23}$ Hal tersebut juga disampaikan AM. Hendropriyono ${ }^{24}$ bahwa timbul-tenggelamnya terorisme di Indonesia disebabkan oleh karena tidak terdeteksinya otak pelaku teror tersebut. Pelaku yang berhasil diringkus merupakan kaki sebagai pelaksana gerakan, sehingga gerakan tersebut akan bersifat laten, sewaktu-waktu dapat dibangkitkan kembali.

Sebagai upaya preventif terhadap ekses negatif gerak dinamis ideologi tersebut, diperlukan filter memadai sebagai perimbangan pertumbuhan radikalisasi melalui teknologi tersebut. Menyadari gerakan tersebut bukan semata-mata sebagai gerakan fisik, maka apa yang perlu diantisipasi adalah bagaimana gerak pemikiran radikalisme sebagai motif aksi terorisme dapat diminimalisasi pergerakannya. Telah disinggung di atas, bagaimana radikalisme berasal dari pemaknaan yang demikian bebas terhadap suatu teks tertentu, harus dilawan dengan pemikiran sistematis, dengan catatan kaki memadai. Terlebih khazanah pemikiran Islam telah berkembang sedemikian luas dan tidak lekang oleh zaman sebagai rahmatan lil alamin.

Menjadi tanggung jawab besar PTKIN sebagai kepanjangan tangan Kementerian Agama Republik Indonesia untuk terus dapat menjaga keutuhan pemahaman terhadap Pancasila sebagai ideologi Bangsa Indonesia dan konstitusi UUD 1945 melalui pendidikan dan kajian keislaman. Dalam upaya deradikalisasi dan pencegahan terhadap aksi terorisme, setidaknya PTKIN memiliki 3 peran penting, yaitu: (i) sebagai jembatan keilmuan dalam perspektif keislaman sehingga dapat dijadikan rujukan pengetahuan masyarakat luas; (ii) penerjemah nilai universal Islam yang dijawantahkan

${ }^{23}$ Ismail, H., dan Naipospos, BT., Dari Radikalisme Menuju Terorisme: Studi Relasi dan Transformasi Organisasi Islam Radikal Di Jawa Tengah dan D.I. Yogyakarta (Jakarta: Pustaka Masyarakat Setara, 2012), hlm. 12-14.

${ }^{24}$ Hendropriyono, Abdullah M., Terorisme dalam Filsafat Analitika: Relevansinya dengan Ketahanan Nasional, Disertasi (Yogyakarta: Universitas Gadjah Mada, 2009) 
dan ditegaskan dalam ideologi kebangsaan, Pancasila; (iii) memperkuat daya dukung Sistem Pertahanan dan Keamanan Rakyat Semesta (Sishankamrata).

Filter terhadap radikalisme sebagai konstruksi ideologi, dilakukan dengan produksi pengetahuan memadai, diproduksi memalui proses keilmuan, dan bersifat populer sehingga masyarakat dengan mudah mengaksesnya. Dalam hal ini PTKIN dapat berperan sebagai lembaga sebagai jembatan antara pengetahuan memadai kepada masyarakat. Peran tersebut diejawantahkan dalam Tri Dharma, melibatkan kajian kontemporer dalam frame keislaman, sehingga antara pemenuhan kebutuhan rohaniah (vertikal) dengan kebutuhan lahiriyah (horizontal) masyarakat dapat terpenuhi dengan baik tanpa mengorbankan salah satunya. Berbagai kajian yang dilakukan oleh PTKIN akan mereproduksi pengetahuan yang dapat dikonsumsi masyarakat luas, berasas kemanfaatan, dan memunculkan alternatif-alternatif pemahaman sehingga nilai Islam tersebut tidak terkesan bermakna tunggal-sempit, serta meninggalkan keluwesan dan kemampuannya dalam mengatasi masalah-masalah kontemporer.

Peran lain PTKIN adalah sebagai penerjemah nilai luhur universal yang terdapat dalam dua ideologi, yakni nilai ideologi Islam sebagai ideologi keagamaan yang mengikat penganutnya, dan Pancasila sebagai ideologi bangsa yang mengikat warga negara Indonesia. Fakta penting diungkap oleh AM. Hendropriyono, ${ }^{25}$ yakni kelompok radikalis menginvestasikan konstruksi ideologi melalui dua hal, yakni "ketakutan" dan "doa". Ketakutan dimanifestasikan dalam bentuk dikotomi antara "bagian" dan "nonbagian", atau Islam dan non-Islam. Apapun maupun siapapun yang tergolong dalam "non-bagian" selalu dilibatkan dalam ruang-ruang narasi penghukuman, pesakitan, dan alinasi. Sebaliknya, "doa" merupakan aksi yang dapat diterima jika pelakunya merupakan "bagian" dari kelompoknya. Dikotomi tersebut dalam konteks kebangsaan pada akhirnya akan mempertentangkan ideologi secara harfiah, yakni antara Islam dan Pancasila, sehingga bentuk keindonesiaan juga menjadi bermasalah.

${ }^{25}$ Hendropriyono, Abdullah M., Terorisme dalam Filsafat Analitika: Relevansinya dengan Ketahanan Nasional, Disertasi (Yogyakarta: Universitas Gadjah Mada, 2009) 
Akan menjadi berbeda ketika pandangan terhadap keduanya diletakkan sebagai nilai universal. Tidak terdapat pertentangan di antara keduanya, universalitas nilai merupakan kesemestaan utuh yang tidak dapat dipisahkan satu sama lain. Sebagaimana nilai ketuhanan, kemanusiaan, persatuan, musyawarah-kemufakatan, dan keadilan merupakan nilai-nilai yang secara ontologis merupakan syarat keteraturan (cosmic) atas kehidupan, baik individual, kemasyarakatan, atau hubungan kausalitas antara manusia dengan alam dan Tuhannya. Dalam narasi yang lebih lugas, PTKIN seharusnya mampu menjelaskan kepada masyarakat, antara ritus dengan nilai yang melekati antara dua ideologi tersebut.

Hal tersebut juga bukan bermakna sebagai dualisme ideologi masyarakat. Di awal era kemerdekaan Indonesia, seorang pemikir Islam, Buya Hamka26, telah memberikan pandangan bahwa sila I (pertama) merupakan urat tunggangnya Pancasila, meskipun pengamalan terhadap rukunnya harus utuh dijalankan bersamaan dengan keempat sila lainnya. Arti pandangan tersebut adalah "Ketuhanan yang Maha Esa" merupakan suatu daya hidup dari Pancasila, mendasari keempat sila lainnya. Bersamaan dengan hal tersebut, pandangan tersebut juga memiliki arti bahwa Pancasila sebagai ideologi bangsa menjamin atas nilai keagamaan Islam mendasari kehidupan berbangsa dan bernegara, sedangkan perlindungan atas ritus keagamannya dijamin oleh konstitusi.

Peran penting terakhir PTKIN dalam upaya deradikalisasi dan antisipasi aksi terorisme terstruktur adalah sebagai ruang penyiapan organ Sistem Pertahanan dan Keamanan Rakyat Semesta (Sishankamrata). Seperti apa yang sedikit disinggung di atas, salah satu keberhasilan Orde Baru dalam menekan aksi terorisme adalah bagaimana rezim tersebut dapat memaksimalkan peran pertahanan dan keamana, meski berkecenderungan militeristik (military heavy). Hal tersebut dapat dilihat dalam gagasan "Dwifungsi Angkatan Bersenjata Republik Indonesia (ABRI)-sekarang Tentara Nasional Indonesia (TNI)-pen.". Bukan tanpa alasan gagasan tersebut dicetuskan pada era tersebut, yakni latar belakang trilogi pembangunan nasional terutama pada poin pertama menekankan pada stabilitas nasional yang dinamis.

${ }^{26}$ Hamka, Urat Tunggang Pantjasila (Jakarta: Pustaka Keluarga, 1951: 7-8) 
Stabilitas nasional yang dimaksud adalah menguatkan organ pertahanan dan keamanan tersebut-TNI dan Polri-sehingga pers dan aksi masyarakat termasuk mahasiswa dapat dikendalikan sepenuhnya oleh organ tersebut.

Penguatan Sishankamrata era orde baru didasari payung hukum melalui UU No. 20 Tahun 1982, melibatkan empat komponen pertahanan dan keamanan negara meliputi: (i) komponen dasar rakyat terlatih; (ii) komponen utama ABRI; (iii) komponen perlindungan masyarakat; dan (iv) komponen pendukung lain meliputi sumber daya alam maupun buatan, serta sarana dan prasarana menyeluruh, terpadu dan terarah. Meskipun landas hukum tersebut melibatkan komponen rakyat sebagai suatu realitas luas, gagasan dwifungsi tersebut menyisakan pergulatan makna, sehingga peran dari alat pertahanan dan keamanan negara saling tumpang tindih dan overlapping hingga kepada hak kebebasan sipil. Pada kondisi lebih ketat, seringkali tumpang tindih tersebut termaknai sebagai suatu aksi represif terhadap hak warga negara dalam perspektif demokrasi.

Tumpang tindih yang dimaksud dapat dilihat dalam prinsip "kekaryaan" di tubuh ABRI. Dalam praktik politik, anggota TNI atau Polri aktif dapat mengemban jabatan sipil, bahkan perannya tidak lagi netral sebagai alat pertahanan dan keamanan negara tetapi lebih kepada skema instrumentasi rezim untuk mengatur kehidupan politik. Munculnya Fraksi ABRI di era tersebut merupakan gestur politik yang dapat digunakan sebagai tonggak pemahaman di dalamnya. Hingga pembacaan terhadap fenomena tersebut maka akan dapat dipahami dengan mudah, bagaimana radikalisme di era tersebut dapat mati sebelum tumbuh, mengingat sifat sentralistik rezim tidak akan membenarkan suara apapun kecuali suara rezim itu sendiri.

Tantangan menjadi berubah signifikan pasca gerakan reformasi 1998. Sishankamrata tidak dapat dimaknai begitu saja sebagai intervensi militer sebagai wujud despotisme terhadap sipil. Melalui Ketetapan MPR No. VI/MPR/2000 dan Ketetapan MPR No.VII/MPR/2000 tentang pemisahan kelembagaan pertahanan dan keamanan-TNI untuk bidang pertahanan dan Polri bidang keamanan-maka bersamaan dengan hal tersebut dwifungsi ABRI juga dihapuskan. Sishankamrata di era 
JRTIE: Journal of Research and Thought of Islamic Education

Vol. 3, No. 1, 2020

pasca reformasi masih eksis dengan menempatkan TNI sebagai alat pertahanan negara, kemudian Polri sebagai alat keamanan negara. Pelibatan rakyat dalam konteks sipil masih dipertahankan sebagai daya dukung dua alat dimaksud. Dasar konstitusional dari Sishankamrata tersebut terletak pada pasal 27 ayat 3 dan pasal 30 UUD 1945 amandemen VI. ${ }^{27}$

Nordholt dan Klinken, ${ }^{28}$ menjelaskan bahwa perubahan struktur politik dari Orde Baru kepada Era Reformasi merubah asas kekuasaan dari sentralistik menjadi desentralistik. Hal tersebut menyebabkan kesukaran negara mendapatkan loyalitas dalam masyarakat. Kemandirian dengan pluralitas yang tinggi masyarakat sipil, ekonomi, maupun politik membuat relasi baru antar aktornya sehingga muncul jarak dalam hal hubungan pengendalian masyarakat oleh pemerintah.

Dalam kaitannya dengan radikalisme dan terorisme, maka di era pasca reformasi Sishankamrata memiliki tantangan yang terletak dalam tubuh masyarakat itu sendiri, sebagai entitas otonom yang seharusnya mampu menjelma sebagai faktor pendukung dan bukan sebaliknya menjadi ancaman baru bagi pertahanan dan keamanan nasional. Peran inilah yang seharusnya mampu diampu oleh PTKIN dalam mendukung Sishankamrata, dengan cara membuka ruang pendidikan kewarganegaraan yang memadai. Ruang pendidikan yang dimaksud melibatkan aktivitas keilmuan, keislaman, dan keindonesiaan secara terpadu, proporsional, serta bersifat terbuka sehingga konstruksi ideologi Pancasila dalam alam pikiran masyarakat luas dapat ditransformasikan secara berkemandirian dan berkesadaran.

Daya dukung PTKIN terhadap Sishankamrata tersebut pada akhirnya tidak hanya berkutat pada sistem nilai yang bersifat pasif, melainkan juga mendorong transformasi nilai dan ideologi kepada pemahaman masyarakat tersebut sehingga kontrol bagi pluralitas arbitrer. Maksudnya adalah bagaimana konstruksi ideologi yang telah

27 Suwito, Anton, Sishankamrata Sebagai Upaya Peningkatan Ketahanan Nasional, dalam makalah Seminar Nasional Keindonesiaan II: Strategi Kebudayaan dan Tantangan Ketahanan Nasional Kontemporer, hal. 138-151 (Semarang: FPIPSKR Universitas PGRI, 2017), hlm. 140-141.

28 Dalam Pratikno, Rekonsilidasi Reformasi Indonesia: Kontribusi Studi Politik dan Pemerintahan Dalam Menopang Demokrasi dan Pemerintahan Efektif, Pidato Pengukuhan Jabatan Guru Besar Fakultas Ilmu Sosial dan Politik Universitas Gadjah Mada 21 Desember 2009 (Yogyakarta: Universitas Gadjah Mada, 2009). 
dipahami oleh masyarakat ilmiah melalui output dan outcome aktivitas didalamnya secara aktif dan massif dapat menjadi figur dan rujukan memadai bagi kecepatan informasi dan komunikasi liar di dalam masyarakat.

Seperti yang diketahui bersama, PTKIN tidak hanya memproduksi pengetahuan agama saja, melainkan melibatkan proses dan kewenangan ilmiahnya sehingga output dan outcome yang dihasilkan akan bersifat sistemik. Satu Perguruan Tinggi Keagamaan Islam akan menghasilkan ilmuwan, analis, guru, atau bidang-bidang profesional lain sebagai produsen maupun agen pengetahuan yang bersinggungan langsung dengan multi-ideologi. Satu guru agama yang dihasilkan dengan pola pemikiran humanis akan memberikan harapan atas sokongan pembangunan, dan sebaliknya, apabila yang dihasilkan gaya fatalistik, maka cenderung menampilkan potensi generasi destruktif.

\section{MODEL PEMBELAJARAN TERINTEGRATIF MATA KULIAH PENDIDIKAN KEWARGANEGARAAN SEBAGAI UPAYA TRANSFORMASI IDEOLOGI PANCASILA}

Membicarakan sistem pendidikan pendidikan di Indonesia tidak terlepas dari Capaian Pembelajaran Lulusan (CPL) sesuai dengan Kerangka Kualifikasi Nasional Indonesia (KKNI). Demikian pula dengan bidang kajian-kajian di dalamnya, termasuk dalam hal ini kajian Pendidikan Kewarganegaraan, maka CPL-KKNI merupakan muara dari rangkaian proses yang melingkupinya. Rumusan atas capaian paling sederhana dalam kajian tersebut adalah bagaimana setiap peserta didik di dalamnya dapat hidup dan bersosialisasi dalam masyarakat dengan ketaatan yang berkesadaran terhadap ideologi dan konstitusi.

Sebagaimana telah disinggung sebelumnya, pola interaksi sosial era kontemporer bergerak sedemikian rumit sehingga berimplikasi terhadap tatanan luas. Teknologi komunikasi dan informasi kontemporer sejatinya telah memberikan tawaran pengetahuan yang sedemikian kaya, hanya saja pengetahuan tanpa catatan kaki memadai akan menimbulkan suatu disrupsi berbentuk umpan balik destruktif bagi penyerapnya, yaitu masyarakat akademik dan berimplikasi kepada seluruh masyarakat Indonesia. Teknologi tersebut menjelma menjadi etalase ideologi dengan kemasan 
menarik dan desain praktis. Hanya saja tidak semua ideologi yang ditawarkan layak untuk dikonsumsi masyarakat. Pada posisi ini lah peran Pendidikan Kewarganegaraan dapat memberikan sumbangsih nyata sebagai pengawal pengetahuan masyarakat, dalam hal ini khususnya melalui lembaga pendidikan keagamaan Islam.

Ideologi merupakan salah satu pilar penting dalam konsep geostrategi di Indonesia dan memiliki peranan signifikan dalam mempengaruhi dinamika kehidupan berbangsa. Seringkali pemahaman tentang ideologi dilekatkan pada pendidikan agama, moral, atau etika. Meskipun demikian, afirmasi tanpa ketelitian terhadapnya juga akan menimbulkan masalah baru. Sebagaimana pandangan Haryatmoko, ${ }^{29}$ bahwa letak pergeseran ideologi tidak hanya disebabkan oleh presensi pelajaran agama dalam skema pendidikan. Permasalahannya justru terletak bagaimana pengampu memberikan penjelasan terhadap nilai yang ditafsirkan. Kecenderungan disrupsi materi bergantung pada subjek penafsir, bagaimana aras tujuan pembelajaran dibentuk.

Menafsirkan pandangan tersebut dengan cara berbeda, bermakna juga bahwa ideologi yang sering disebut sebagai kajian usang ternyata memiliki daya tarik tersendiri bagi masyarakat. Beberapa kalangan masyarakat memang telah menunjukkan fenomena laku apatis terhadap diskursus ideologi. Teknologi aplikatif sering dianggap telah menggantikan peran ideologi untuk memandu sekaligus memudahkan kehidupan manusia. Sikap apatis tersebut didorong oleh kemudahan, kesejahteraan, kemapanan, dan kelestarian. Kondisi tersebut menjadi paradoks bagi kalangan lain yang tidak dapat mengakses fasilitas maupun kemapanan yang sama. Kemiskinan dan ketidakmampuan akan meletakkan ideologi sebagai cara pandang untuk menghapuskan adjektiva negatif seperti halnya ketimpangan dan ketidakadilan. Memiliki arti yang sama, bahwa ideologi merupakan wadah, sarana, cita-cita maupun tujuan bagi kalangan tertentu, sehingga hal tersebut akan menjadi alasan untuk bergerak.

Kemunculan fatalisme dan radikalisme, bukan semata-mata muncul sebagai dongeng pengantar tidur, melainkan menjadi sebuah alasan untuk memperjuangkan tujuan hidup. Kemudian dalam tataran aksi, ideologi tidak lagi menjadi gambaran pasif

${ }^{29}$ Haryatmoko, Etika Politik dan Kekuasaan (Jakarta: Gramedia, 2004), hlm. 113. 
yang meringkuk di kamar pikir, melainkan akan meledak untuk mengejutkan siapapun. Kontemplasi tersebut dapat dilihat melalui deskiripsi atas aksi teror yang dilatarbelakangi oleh paham radikal, atau radikalisme mendorong terorisme, maka hal tersebut akan bersentuhan dengan masyarakat keseluruhan, termasuk di dalamnya mereka yang apatis terhadap ideologi. Kejutan tersebut akan melemparkan pertanyaan untuk diterka-terka: bagaimana orang dapat meledakkan bom di perutnya untuk melukai orang lain? Beberapa penerkaan akan menunjuk kesalahan subjek aktor di baliknya, dan beberapa yang lain akan mempertanyakan bagaimana sistem pendidikan telah membentuknya. Hal menarik lain justru akan terletak pada keterlibatan semua pihak atas kejadian tersebut. Dalam arti lain, kalangan yang apatis terhadap ideologi pun akan bersibuk dengan hal yang tak pernah dipikirkannya.

Menjawab persoalan tersebut dapat diulas melalui pembahasan pendidikan sebagai sistem yang utuh. Pendidikan yang meletakkan pebelajar sebagai objek akan menempatkan manusia dalam cara pandang fatalistik, magis, dan naif. Penindasan terhadap kesadaran yang disebabkan oleh pendidikan, justru akan menempatkan manusia dalam ruang isolasi-individual, menjauhkan diri kepada solidaritas, membuat jarak antagonistik antara penindas dengan yang tertindas-yakni antara pembelajar dan pebelajar itu sendiri. ${ }^{30}$ Berkaitan dengan pandangan Freire tersebut, dalam pembahasan dengan perspektif konteks yang lebih luas, akan menempatkan pendidikan dikotomis sebagai pengantar atas pergeseran subjek terdidik-yakni masyarakat-menjadi objek tertindas. Lembaga pendidikan, khususnya perguruan tinggi pada dasarnya selain berkewajiban membentuk keahlian peserta didik melalui bidang-bidang tertentu yang diampu oleh fakultas di bawahnya, juga dituntut untuk mampu mengintegrasikan etika sosial yang melingkupinya. Suatu keahlian tanpa dibentuk oleh karakter moral memadai, justru akan menjadikan individu yang melekatinya sebagai wujud yang naif dan mengantarkannya kepada ruang isolasi sosial.

Solusi yang dapat diajukan adalah rekonstruksi terhadap bangun usang ideologi di dalam kehidupan masyarakat melalui pola pendidikan kepribadian yang berbasis

${ }^{30}$ Paulo Freire, Pendidikan Kaum Tertindas (Jakarta: LP3S, 2011), hlm: 72-73. 
JRTIE: Journal of Research and Thought of Islamic Education

Vol. 3, No. 1, 2020

individual interest menjadi institutional-konstitutional interest yang didasarkan pada materi pengembangan kepribadian. Menjadi tanggung jawab Pendidikan Kewarganegaraan, dalam hal ini khususnya di PTKIN, untuk menransformasikan ideologi kebangsaan tanpa harus mempertentangkan nilai-nilai universal di dalamnya. Untuk materi yang dapat diajukan dalam mata kuliah tersebut adalah dengan mengidentifikasi persinggungan nilai identitas yang mencirikan dua subjek formalnya, yakni keislaman maupun keindonesiaan. Pendekatan yang dapat dilakukan oleh kajian tersebut adalah menggunakan model kontekstual, tematik, dan terintegratif.

Dalam ranah praksis, persinggungan antara nilai dengan fenomena faktawi dapat diarahkan kepada pembelajaran kontekstual (contextual learning). Hakikat pembelajaran tersebut merupakan suatu strategi pembelajaran yang berorientasi pada keterlibatan peserta didik, meliputi upaya penemuan dan pemahaman materi teoritik hingga merelevansikan kepada kehidupan keseharian. ${ }^{31}$ Senada dengan hal tersebut, Freire ${ }^{32}$ dalam konteks lebih luas memberikan pandangan bahwa pendidikan harus diarahkan kepada pendidikan dialogis. Melibatkan pembelajar-pebelajar dalam rangkaian model "hadap-masalah", yakni secara bersama-sama dalam suatu proses pembelajaran dialogis, kontekstual, sistematik, dan secara berkelanjutan dikembangkan.

Makna kontekstual dan hadap masalah tersebut, dimaksudkan mempertemukan nilai dan fakta yang terjadi di dalam kehidupan keseharian. Pembelajar maupun pebelajar harus mampu mengidentifikasi dan menginvestigasi hubungan antara input teoritik dan penerapannya di lapangan. Sebaliknya, pendidikan akan menjadi kontra produktif ketika pendidikan gaya bank yang hanya meletakkan pebelajar sebagai ruang penyimpanan pengetahuan. Pendidikan gaya bank hanya akan menempatkan pembelajar akan menjadi penyaji tunggal yang membosakan ketika hanya melakukan kegiatan "penyajian ulang" atas teori-teori yang telah mapan. Terlebih disiplin Pendidikan Kewarganegaraan senantiasa terhubung oleh masalah sosial yang baru. Sebagaimana dinamika politik pada suatu negara akan mempengaruhi isi maupun

${ }^{31}$ Wina Sanjaya, Strategi Pembelajaran Berorientasi Standar Proses (Jakarta: Kencana, 2009), hlm. 255. hlm. 85 .

32 Paulo Freire, Pendidikan yang Membebaskan, Terj. Martin Eran (Jakarta: Media Lintas Batas, 2001), 
praktik hukum di negara tersebut, maka hal tersebut secara berantai akan mempengaruhi aksi maupun reaksi warga negara di dalamnya.

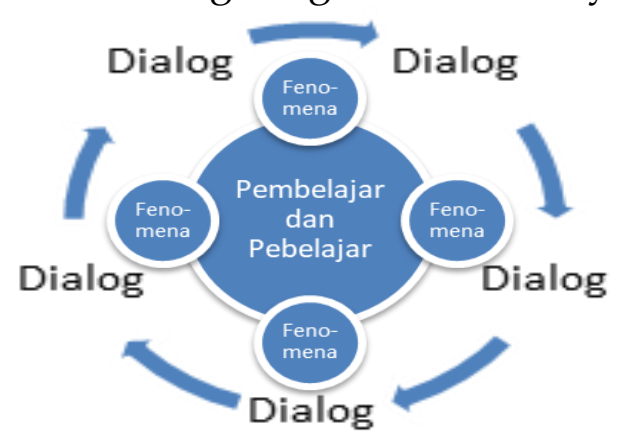

\section{Gambar 1. Skema Pembelajaran Dialogis}

Pendidikan kontekstual secara berkelanjutan berpotensi untuk memberdayakan daya kritis pebelajar, sehingga transformasi nilai ideologi akan dilakukan secara sadar. Daya kritis tersebut bersifat skeptis terhadap stigma dan dogma, sebagai kontradiksi dari pola radikalisasi. Tidak berarti pembelajaran tersebut menolak iman, kalam, maupun kewahyuan yang melekat pada ideologi agama. Justru lebih berujuk pada pendidikan dewasa yang haus akan kecermatan, ketelitian, dan membentuk suatu wacana kajian yang berkelanjutan.

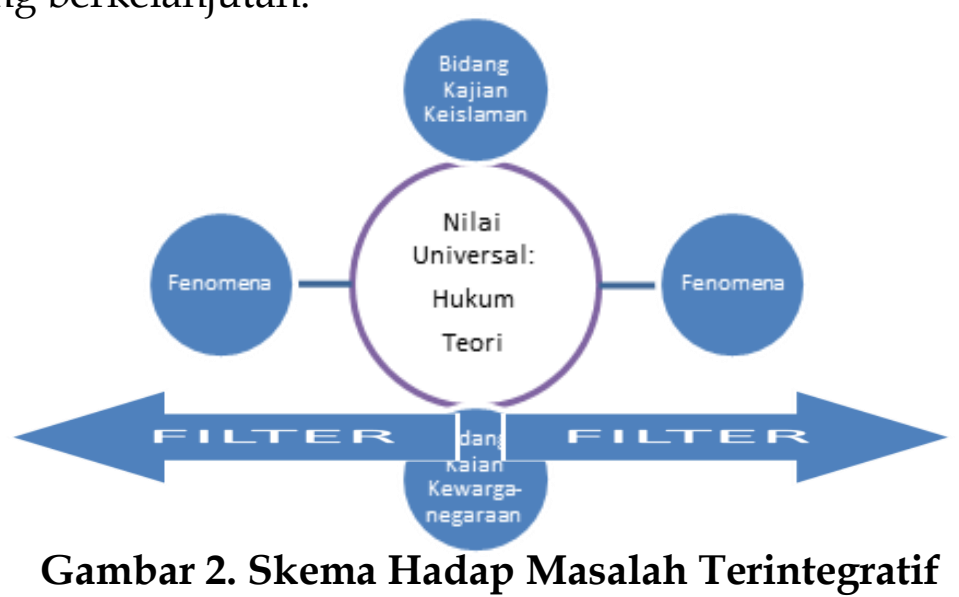

Paradoks dengan pola rekrutmen radikalisasi, penelitian AM. Hendropriyono ${ }^{33}$ menunjukkan bahwa transformasi ideologi lebih menggunakan manipulasi bahasa terhadap ungkapan kebenaran yang bersumber pada teks-teks kitab suci. Radikalisasi tersebut lebih mirip pola pendidikan gaya bank, yakni menempatkan pebelajar - dalam

33 Hendropriyono, op.cit. 2009. 
JRTIE: Journal of Research and Thought of Islamic Education

Vol. 3, No. 1, 2020

hal ini disebut calon simpatisan maupun pengikut-sebagai ruang penyimpan pengetahuan pasif, dengan gaya bahasa yang manipulatif dan dramatis. Dalam lingkaran kelompok tersebut tidak diperkenankan mengajukan daya kritis untuk meneliti kembali kepada materi kaidah agama yang pernah disampaikan.

Radikalisasi dalam konteks pola stigmasi terhadap nilai, akan cenderung mandul jika dihadapkan pada kontekstualisasi. Pola kontekstualisasi dalam kajian strategi pembelajaran, akan membentuk pola tematik sehingga bahan kajian lebih terarah. Pembelajaran tematik merupakan pembelajaran terpadu (integrated learning and teaching), melalui pola kurikulum terpadu (curriculum approach). ${ }^{34}$ Dengan pola terpadu tersebut, diharapkan pertalian pemahaman utuh dengan ketersusunan nalar yang dicerap melalui keutuhan nilai dan fakta, ruang dan waktu.

Tabel 1.

Contoh Integrasi Materi Interdisipliner Dalam MKWU Kewarganegaraan

\begin{tabular}{|c|c|c|c|c|c|c|c|c|}
\hline Pert. & $\begin{array}{l}\text { Indikator Capaian } \\
\text { Pembelajaran }\end{array}$ & Bahan Kajian & $\begin{array}{l}\text { Bentuk dan } \\
\text { Metode } \\
\text { Pembelajaran }\end{array}$ & Waktu & $\begin{array}{l}\text { Pengalaman } \\
\text { Belajar }\end{array}$ & $\begin{array}{c}\text { Indikator dan } \\
\text { Kriteria } \\
\text { Penilaian }\end{array}$ & Bobot Nilai & Rujukan \\
\hline $\begin{array}{l}(1) \\
13\end{array}$ & \begin{tabular}{ll}
\multicolumn{1}{c}{$(2)$} \\
a. & Mahasiswa/i mampu \\
memahami ketiadaan \\
pertentangan antara \\
konsep Islam dalam \\
perspektif agama dan \\
kepercayaan, dengan \\
Pancasila sebagai dasar \\
negara; \\
b. Mahasiswa/i mampu \\
memahami dan \\
menganalisa konsep \\
sosial Islam, sekaligus \\
dapat memilahkan \\
dengan gerakan \\
radikalisme; \\
c. Secara aplikatif \\
Mahasiswa mampu \\
menganalisa \\
keterkaitan antara nilai \\
Islam sebagai tonggak \\
konstitusi modern dan \\
Pancasila sebagai dasar \\
negara.
\end{tabular} & $\begin{array}{l}\text { Pilar Kesatuan } \\
\text { Bangsa: Peran } \\
\text { Islam dalam } \\
\text { Kesatuan Bangsa }\end{array}$ & $\begin{array}{ll}\text { a. } & \text { Pembelajaran } \\
& \text { Kolaboratif } \\
\text { b. } & \text { Simulasi } \\
\text { c. } & \text { Diskusi } \\
& \text { Kelompok }\end{array}$ & $\begin{array}{ll}\text { a. } & \text { TM } \\
\text { b. } & 2^{* 50} \\
\text { bT } & 2^{* 50}\end{array}$ & \begin{tabular}{|l|}
\multicolumn{1}{|c|}{$(6)$} \\
a.
\end{tabular} $\begin{array}{l}\text { Pembelajaran } \\
\text { dialogis } \\
\text { berbasis } \text { - } \\
\text { learning atau } \\
\text { pembelajaran } \\
\text { kelas secara } \\
\text { tentatif sesuai } \\
\text { dengan status } \\
\text { otoritas terkait } \\
\text { tentang } \\
\text { pandemi } \\
\text { Covid-19 } \\
\text { b. Kerjasama } \\
\text { pada } \\
\text { kelompok kecil } \\
\text { c. Penguraian } \\
\text { masalah } \\
\text { berbasis } \\
\text { wacana } \\
\text { (discourse and } \\
\text { method) }\end{array}$ & $\begin{array}{ll}\text { a. } & \text { Sikap } \\
\text { b. } & \text { Keterampil } \\
& \text { an Umum } \\
\text { c. } & \text { Keterampil } \\
& \text { an Khusus }\end{array}$ & $\frac{1}{16} \cdot 30 \% \cdot 100$ & (9) \\
\hline
\end{tabular}

Pembelajaran tematik dalam Pendidikan Kewarganegaraan di PTKIN dapat diarahkan pada berbagai wacana yang membentuk karakter berbasis kebhinekaan, pluralisme, dan kearifan lokal tanpa meninggalkan pokok ajaran Islam sebagai identitas keilmuan dan institusi. Tidak terdapat pertentangan terhadapnya, sebagaimana Islam mengajarkan perdamaian atas keragaman, demikian juga dengan Pancasila. Tema

${ }^{34}$ Abdul Kadir dan Asrohah, H., Pembelajaran Tematik (Jakarta: Raja Grafindo Persada, 2015), hlm. 5. 
pembelajaran dapat disesuaikan dengan panduan yang terdapat dalam visi dan misi Pendidikan Kewarganegaraan dengan diskursus Islam populer dan aplikatif yang dekat dengan kehidupan warga negara.

Tentu saja hal tersebut akan melibatkan kajian-kajian dari rumpun disiplin Pendidikan Agama Islam, seperti: Sejarah Kebudayaan Islam, Fikih, Filsafat Pendidikan Islam, dan sebagainya. Desain kurikulum terintegrasi antar mata kuliahnya, artinya terdapat keterpautan yang berkelanjutan antar pokok bahasannya. Misalnya materi bahasan tentang keadilan sosial dengan sub-tema distribusi properti. Materi dapat dikembangkan melalui persinggungan diantara keduanya, meliputi distribusi properti dan kepemilikan individu yang diatur dalam konstitusi UUD 1945, dan bagaimana konsep baitul maal dalam Islam mengatur. Demikian pula materi yang berkaitan dengan sosiodemokrasi, dapat dilihat bagaimana konstitusi mengatur keragaman etnis, sosioreligi, maupun kontrak sosial yang berlaku kemudian disandingkan dengan konsep sosiodemokrasi yang telah ada di Piagam Madinah. Penyandingan tersebut merupakan bentuk dialog dua konsep berbeda dengan nilai sama. Tentu saja akan ditemui banyak praktik dan aplikasi berbeda mengingat penerapannya dilakukan pada dua zaman dan kondisi masyarakat berbeda. Apa yang paling penting diantara keduanya adalah pada nilai pembahasan dengan frekuensi seimbang.

Integrasi materi sebagaimana dimaksud bukan lah suatu upaya sinkretisme, menyampuraduk kepercayaan yang telah ada dalam Islam, atau sebaliknya. Hal tersebut untuk menunjukkan bahwa nilai kebenaran yang telah dibawa Islam juga secara an sich merasuki Pancasila. Dalam arti lain, materi integratif akan mengantarkan pebelajar kepada himpunan realitas sosial. Muara dari pendidikan bukan lah tanda tamat belajar dengan grade tertentu. Bagaimanapun juga, pebelajar merupakan entitas otonom yang harus diberdayakan daya kritisnya, karena pada titik tertentu entitas tersebut akan melebur pada semesta realitas sosial yang sedemikian luas, dan saling bersinggungan satu sama lain. Keberhasilan transformasi ideologi dalam Pendidikan Kewarganegaraan adalah bagaimana pebelajar-peserta didik-nantinya mampu 
melayani masyarakat luas tanpa pembedaan. Nilai terpadu yang bersemayam dalam Islam dan Pancasila, harus dapat diejawantahkan dalam kehidupan keseharian.

\section{E. PENUTUP}

Menempatkan manusia dalam subjek penting bagi kehidupan di dunia, berarti mendasarkan ideologi sebagai cita-cita sekaligus hasil olah pemikiran manusia ini untuk membangun kehidupan yang lebih baik. Kompleksitas bangunan pemikiran menimbulkan varian ideologi yang beranekaragam, termasuk di dalamnya radikalisme dan terorisme. Hanya saja, hal tersebut harus dapat difiltrasi dengan lebih bijak, terlebih konsep nation-state Indonesia telah hadir utuh dengan cita-cita keadilan sosial yang tidak dapat memihak pada kalangan tertentu.

PTKIN hadir sebagai lembaga pendidikan, sebagai lembaga perwakilan pemerintah untuk memajukan bidang pendidikan dengan karakteristik khas bersanding dengan identitas keislaman. Sebagai negara non-sekuler, Indonesia mewadahi berbagai ideologi yang sesuai dengan nilai Pancasila sebagai landas pijak komunal, pengikat identitas kebangsaan tersebut. Oleh karena itu, Pancasila akan selalu bersifat terbuka selama sesuai dengan 5 (lima) sila pembentuknya.

Permasalahan yang harus disadari adalah keniscayaan adanya jarak antara nilai dengan fakta, dan nilai dengan peristiwa. Nilai tidak akan bergerak selama subjek pengampunya tidak mewujudkannya. Berdasarkan pijakan tersebut lah alasan Pendidikan Kewarganegaraan hadir di PTKIN. Tentu saja kehadirannya semata-mata diletakkan sebagai alat pengontrol atas kebebasan mimbar ilmiah. Menjadi lebih penting bagaimana program tersebut dapat dimaknai sebagai salah satu wadah pendobrak daya kritis civitas academica di PTKIN.

Sinergi antara dua subjek otonom, Pendidikan kewarganegaraan dan PTKIN justru akan menampilkan transformasi ideologi Pancasila yang lebih humanistik. Metode integrasi yang melibatkan kontekstualisasi dan keterpaduan antar nilai pada kurikulum pendidikan keduanya, akan dapat dengan mudah ditafsirkan oleh kalangan akademisi untuk mencermati dinamika sosial dalam masyarakat. Daya kritis tersebut juga 
diharapkan akan lebih cermat dalam menghadapi serangan informasi arbitrer yang secara sporadis ditampilkan oleh teknologi informasi dan komunikasi.

Wujud keberhasilan tertinggi atas keberadaan Pendidikan Kewarganegaraan di PTKIN adalah mampu memerdekakan para peserta didik di dalamnya, sebagai ahli, ilmuwan, maupun profesional sesuai bidang keilmuan, tanpa meninggalkan identitas keislaman dan keindonesiaan. Selanjutnya, transformasi tersebut pada akhirnya akan menciptakan agen-agen ideologi Pancasila di lingkungan masyarakat dalam rangka misi kemanusiaan, persatuan kebangsaan baik nasional maupun internasional, demokrasi permusyawaratan, dan keadilan sosial Indonesia yang dibungkus oleh nilai ketuhanan, sebagai wujud syukur bangsa atas proklamasi kemerdekaan Indonesia 1945.

\section{DAFTAR PUSTAKA}

Darmodiharjo, Darji et.al. Santiaji Pancasila. Surabaya: Usaha Nasional. 1991.

Departemen Agama Republik Indonesia. Pedoman Pelaksanaan P-4 Bagi Umat Islam. Jakarta: Proyek Bimbingan Pelaksanaan P-4 Bagi Umat Beragama. 1983.

Febryan A., 2019. "Radikalisme di Medsos, BNPT Petakan 4 Konten Keagamaan". Media Republika (11 Desember 2019), https://m.republika.com/amp/q2b4os428 diakses pada 20 April 2020.

Freire, Paulo. Pendidikan yang Membebaskan, Terj.: Martin Eran. Jakarta: Media Lintas Batas. 2001.

------. Pendidikan Kaum Tertindas. Terj.: Tim Redaksi. Jakarta: LP3S. 2011.

Ghifari, Imam. Radikalisme di Internet. Jurnal: Jurnal Agama dan Lintas Budaya Vol. I, No. 1, Maret 2017.

Hamka. Keadilan Sosial Dalam Islam. Jakarta: Penerbit Widjaya. 1951.

. Urat Tunggang Pantjasila. Jakarta: Pustaka Keluarga. 1951.

Haryatmoko. Etika Politik dan Kekuasaan. Jakarta: Gramedia. 2004.

Hendropriyono, Abdullah M., Terorisme dalam Filsafat Analitika: Relevansinya dengan Ketahanan Nasional. Disertasi. Yogyakarta: Universitas Gadjah Mada. 2009.

Ismail, H., dan Naipospos, BT., Dari Radikalisme Menuju Terorisme: Studi Relasi dan Transformasi Organisasi Islam Radikal Di Jawa Tengah dan D.I. Yogyakarta, Jakarta: Pustaka Masyarakat Setara.

Kadir, Abd., dan Asrohah, Hanun. Pembelajaran Tematik. Jakarta: Raja Grafindo Persada. 2015. 
Kaelan. Pendidikan Kewarganegaraan Untuk Perguruan Tinggi. Yogyakarta: Paradigma. 2016.

Muthmainnah, L., Muhaimin, H., dan Widodo, SS., “Integrasi ESD dalam Pembelajaran dan Penguatan Metodologi Keilmuan Pancasila bagi Guru di Kawasan Bantul Selatan". Jurnal Indonesian Journal of Community Engagement Vol. 02, No. 01, September 2016.

Pratikno. Rekonsilidasi Reformasi Indonesia: Kontribusi Studi Politik dan Pemerintahan Dalam Menopang Demokrasi dan Pemerintahan Efektif, Pidato Pengukuhan Jabatan Guru Besar Fakultas Ilmu Sosial dan Politik Universitas Gadjah Mada 21 Desember 2009, Yogyakarta: Uninersitas Gadjah Mada. 2009.

Sanjaya, Wina. Strategi Pembelajaran Berorientasi Standar Proses. Jakarta: Kencana. 2009.

Sudjito, Muhaimin, Hendro., dan Widodo, S. Sri. "Pancasila and Radicalism: Pancasila Enculturation Strategies as Radical Movements Prevention", Jurnal Dinamika Hukum Vol. 18, No. 1, Januari 2018.

Suwito, Anton. Sishankamrata Sebagai Upaya Peningkatan Ketahanan Nasional, Seminar Nasional Keindonesiaan II: Strategi Kebudayaan dan Tantangan Ketahanan Nasional Kontemporer. Semarang: FPIPSKR Universitas PGRI. 2017.

Tim Penyusun Kemenristekdikti. Pendidikan Pancasila Untuk Perguruan Tinggi. Jakarta: Direktorat Jendral Pembelajaran dan Kemahasiswaan. 2016.

Van Peursen, Cornelis A. Fakta, Nilai, Peristiwa: Tentang Hubungan Antara Ilmu Pengetahuan dan Etika. Jakarta: Gramedia. 1992. 